\title{
I TIPO CUKRINIO DIABETO SĄSAJA SU IDIOPATINIU JUVENILINIU ARTRITU VAIKŲ AMŽIUJE
}

\author{
Gintarè Gečaitė ${ }^{1}$, Aušra Šnipaitiene் ${ }^{1,2}$, Mantas Malinauskas ${ }^{3}$, Lina Jankauskaitėe ${ }^{2,3}$ \\ ${ }^{l}$ Lietuvos sveikatos mokslu universiteto Medicinos akademija, \\ ${ }^{2}$ Lietuvos sveikatos moksly universiteto ligoniné Kauno klinikos, Vaiku ligu klinika, \\ ${ }^{3}$ Lietuvos sveikatos mokslu universiteto Medicinos akademija, \\ Fiziologijos ir farmakologijos institutas
}

\begin{abstract}
Raktažodžiai: cukrinis diabetas, vaikai, idiopatinis juvenilinis artritas, autoimuninè liga.

Santrauka

Darbo tikslas - įvertinti, susisteminti ir išanalizuoti mokslinejje literatūroje pateikiamus duomenis apie vaikų 1 tipo cukrinio diabeto (CD) sąsajas su idiopatiniu juveniliniu artritu. Šioje sisteminejje apžvalgoje išanalizuoti 32 viso teksto straipsniai. Remiantis atrinktų straipsnių rezultatų duomenimis, galima teigti, kad 1 tipo CD dažniau pasireiškia pacientams, sergantiems juveniliniu idiopatiniu artritu, nei bendrai populiacijai.
\end{abstract}

\section{Ivadas}

Juvenilinis idiopatinis artritas (JIA) yra dažniausia lètinè vaikų uždegiminè reumatinè liga Europoje, apytiksliai 2-20 atvejų 100000 vaikų ir paauglių [1]. Tarptautinė reumatologijos asociacijų lyga JIA suskirstè ị skirtingus potipius, atsižvelgiant ị trukmę, pažeistų sąnarių skaičių bei reumatoidinio faktoriaus (RF) buvimą ar nebuvimą [2]. JIA turi panašumų su reumatoidiniu artritu (RA) dèl artrito uždegiminio pobūdžio ir teigiamo reumatoidinio faktoriaus nedideliame pacientų pogrupyje. Keletas stebejjimo tyrimų parodè padidèjusị cukrinio diabeto dažnį pacientams, sergantiems JIA, ir atvirkščiai, didesnị JIA paplitimą sergantiems 1 tipo CD, lyginant su bendraja pacientų populiacija [3-5]. Nepaisant to, epidemiologinès žinios apie JIA ir 1 tipo CD yra ribotos. Geresnès žinios apie 1 tipo CD ir kitų lètinių autoimuninių ligų, tokių kaip JIA, ryšį, galètų padèti įtarti progresuojančius lètinius procesus ankstyvose stadijose, nustatyti komplikacijas, valdyti ligą ir nustatyti prognozę [6]. Remdamiesi mokslinių tyrimų duomenimis, išanalizuosime ir aptarsime įrodymais pagrịstas sąsajas ir jų reikšmingumą vaikams, vienu metu sergantiems JIA ir 1 tipo $\mathrm{CD}$.
Darbo tikslas - išanalizuoti ir aptarti ịrodymais pagrịstas sąsajas tarp 1 tipo CD ir JIA vaikų populiacijoje.

\section{Tyrimo medžiaga ir metodai}

Taikyta sisteminè mokslinès literatūros bei dokumentų apžvalga ir analizè. Duomenų buvo ieškoma PubMed, Google Scholar, UpToDate, Wiley bei Cochrane duomenų bazėse. Visateksčiai straipsniai atrinkti, jei jų pavadinimas, santrauka ar reikšminiai žodžiai nurodè, kad tyrimas tinkamas šiai apžvalgai. Pasirinktos tik anglų kalba skelbtos publikacijos, pasirodžiusios pastarujų 15 metų laikotarpiu. Vartoti anksčiau nurodyti raktažodžiai. Atrinkti ir apibendrinti 32 straipsniai.

\section{Rezultatai}

Juvenilinis idiopatinis artritas ir 1 tipo cukrinis diabetas: paplitimas ir rizika. Dar $1968 \mathrm{~m}$. aprašytas pirmas pediatrinis pacientas, sirgęs artritu ir cukriniu diabetu [7]. 1 tipo cukrinis diabetas (CD) išlieka dažniausia diabeto forma daugelyje populiacijų, ypač europiečių, atsiranda dèl insulino trūkumo, sunaikinus insuliną gaminančias kasos beta ląsteles [8]. Dažniausiai tai pasireiškia vaikysteje, tačiau ketvirtadalis atvejų diagnozuojami ir suaugusiesiems [9]. Tarptautinès diabeto federacijos atlaso duomenimis, pasaulyje 1 tipo diabetu sergančių vaikų ir jaunesnių nei 20 metų asmenų skaičius viršija 1,1 milijono. Nors pabrezžiama, kad per pastaruosius 19 metų 2 tipo CD dažnis pasaulyje išaugo net 88 proc., tačiau dideja ir 1 tipo CD dažnis vaikų amžiuje [10]. 1 tipo CD išlieka dažniausiai pasitaikanti diabeto forma vaikysteje, kuri JAV sudaro maždaug du trečdalius naujų diabeto atvejų pacientams iki 19 metų, nepaisant didejjančio 2 tipo diabeto dažnio [11]. Lietuvoje padètis ne mažiau grèsminga. Higienos instituto duomenimis, 2019 metais sergančių 1 tipo CD asmenų skaičius buvo 6421, iš jų 818 vaikų bei paauglių nuo 0 iki 17 metų [12]. Pastaruoju metu daugẻja duomenų, kad yra ryšys tarp 1 tipo $\mathrm{CD}$ ir juvenilinio idiopatinio artrito 
(JIA). H. Lee ir kt. (2019) atliktame kohortiniame tyrime, kuriame dalyvavo 15210 pacientų, sergančių JIA, ši pacientų grupè, lyginant su astma ir sveikų gyventojų grupėmis, turèjo dar didesnę riziką susirgti 1 tipo CD. Absoliuti rezultatų rizika šiame tyrime buvo nedidelè. Nustatyta, kad JIA pacientams 1 tipo CD rizika yra 1,48 karto didesne, lyginant su astma sergančiaisiais, o lyginant su sveikais vaikais, rizika išauga iki 1,81 karto. Tyrejjai pastebėjo, kad JIA sergančiuju grupeje padidejusi ir 2 tipo CD išsivystymo rizika, nors ši mažesnè. 2 tipo $\mathrm{CD}$ patogenezė skiriasi nuo 1 tipo $\mathrm{CD}$, todèl manoma, kad JIA ligą provokuojančios uždegiminès reakcijos galètų lemti ir atsparumo insulinui išsivystymą 2 tipo CD sergantiems pacientams [2]. Panašu, kad skirtingos autoimuninès ligos pasireiškia tiems patiems vaikams. S. Schenck ir kt. (2018) nustate, kad padidejęs 1 tipo CD paplitimas tarp pacientų, sergančių JIA. Išvada pagrịsta 12269 pacientų, sergančių JIA, analize iš Vokietijos nacionalinès vaikų reumatologijos duomenų bazès. JIA registre 1 tipo CD paplitimas tarp $<20$ metų asmenų buvo 0,5 procento. Tai beveik dvigubai didesnis 1 tipo CD asmenų, sergančių JIA, paplitimo santykis, palyginti su Vokietijos gyventojais [13]. Kohortiniame tyrime taip pat buvo pranešta apie tai, kad iki 20 proc. pacientų, sergančių tiek 1 tipo $\mathrm{CD}$, tiek JIA, taip pat turèjo kitą autoimuninès ligos sukeltą pažeidimą [13]. Kitame kohortiniame tyrime nustatyta, kad 1 tipo CD paplitimas buvo beveik dvigubai didesnis tarp pacientų, sergančiu JIA, lyginant su bendra populiacija. 1 tipo CD pacientams, sergantiems JIA, pasireiškẻ anksčiau, nei bendroje populiacijoje, o dviem trečdaliams pacientų, sergančių JIA ir 1 tipo CD, 1 tipo CD išsivyste anksčiau, nei JIA. Pradejjus gydymą biologiniais ligą modifikuojančiais antireumatiniais vaistais (LMARV), nè vienam JIA sergančiam pacientui 1 tipo CD neatsirado [3].

JIA ir 1 tipo CD išsivystymo mechanizmai. Daugelio JIA tipų išsivystymo mechanizmas yra autoimuninis. Dvynių ir šeimos tyrimai pabrezžè genetinio polinkio svarbą autoimuninems ligoms [3]. Genetiniai tyrimai parodè, kad tam tikros geno lokusų mutacijos padidina autoimuninių ligų išsivystymo tikimybę. Fenotipiškai skirtingos autoimuninès ligos gali išsivystyti dèl tos pačios genetinès predispozicijos. Buvo nustatyta keletas pavienių nukleotidų polimorfizmų, susijusių su JIA [14]. Dèl šios priežasties pacientai, sergantys viena autoimunine liga, turi polinkị sirgti tokioms autoimuninėmis ligoms, kaip Hashimoto tiroiditas, Adisono liga, celiakija ar autoimuninis gastritas [15]. Aprašytas genetinis ryšys tarp 1 tipo cukrinio diabeto ir JIA. Naudojant ịvairius metodus, įskaitant kandidatų genų tyrimus, aprašyti genotipo rinkiniai, tokie kaip ImmunoChip (Illumina) ir genomo plačios asociacijos tyrimai, aprašyti žmogaus leukocitų antigenai (HLA) ir ne HLA jautrumo lokusai, susiję su JIA [16]. Keletas iš šių polimorfizmų (pvz., HLA II klasė, PTPN22, STAT4) būdingi kitoms dažnai pasireiškiančioms autoimuninėms būklėms, kai kiti nustatyti polimorfizmai gali būti būdingi tik JIA. Žmogaus leukocitų antigenas yra vienas iš didžiojo audinių suderinamumo komplekso (MCH) koduojamų baltymų. HLA antigenus koduojantys genų lokusai yra 6-oje žmogaus chromosomoje. Šie genai yra ypač polimorfiniai ir buvo įrodyta, kad jie susiję su daugybinėmis autoimuninèmis ligomis, ịskaitant reumatoidinị artritą ir 1 tipo cukrinị diabetą [16].

Nors JIA etiologija nėra visiškai suprantama, tačiau yra ịrodymų, kad uždegiminès ląstelès patenka ị sinoviją ir sukelia vietinį uždegimą bei progresuojančius sąnarių pažeidimus. Autoimuninè vaikų artropatija išsivysto iš dalies dèl dviejų jautrumo genų rinkinių susiliejimo. Makrofagų išskiriami citokinai (IL-1, TGF- $\beta$, TNF- $\alpha$, IFN- $\gamma$ ) palaiko uždegimą ir skatina sinovijos ląstelių bei fibroblastų proliferaciją, stimuliuoja sinoviocitus ir chondrocitus sekretuoti proteolizinus bei matricą ardančius baltymus $[16,17]$. Be to, TNF- $\alpha$ ir jo receptoriai yra ekspresuojami JIA sergančių pacientų sinovijoje. TNF- $\alpha$ lokusas yra 6-os chromosomos MHC srityje (6p21.3), tarp klasikinių HLA I ir II klasių genų. TNF- $\alpha$ yra svarbus autoimuniteto patogenezeje, tai patvirtina rastos sąsajos tarp šio lokuso ir skirtingų autoimuninių sutrikimų [18].

Kaip ir dauguma lètinių autoimuninių ligų, 1 tipo CD pasireiškia esant genetiniam polinkiui ir progresuoja, kai suaktyvinta imunine sistema ima atakuoti sveikas kasos beta ląsteles. Kitų autoimuninių ligų išsivystymas priklauso nuo specifinių autoantikūnų gamybos [19]. Naudojant autoantikūnus, gali būti nustatytas specifinis organų autoimunitetas, prieš diagnozuojant klinikinę ligą. Ankstyvas aptikimas gali užkirsti kelią reikšmingam sergamumui, susijusiam su neatpažinta liga [20]. Pagrindinis histologinio suderinamumo kompleksas (MHC) buvo išsamiai ištirtas, sergant šiomis ligomis. Didžiausias 1 tipo CD žmogaus leukocitų antigeno (HLA) genotipas yra DR3-DQ2, DR4-DQ8. Asmenims, kuriems būdingas šis genotipas, yra 5 proc. rizika 1 tipo $\mathrm{CD}$ pasireikšti iki 15 metų amžiaus [21]. Su MHC I yra susijęs genas A (MIC-A), kuris siejamas su autoimuninemis ligomis. MIC-A polimorfizmai grindžiami trigubų vienos iš alaniną koduojančios sekos GCT pakartojimų skaičiumi 5-ame egzone. Papildomas polimorfizmas yra susijęs su bazinès poros įterpimu, dèl kurio susidaro priešlaikinis sustabdymo kodonas. MIC-A polimorfizmai yra siejami su 1 tipo CD ir JIA atsiradimu [22]. Šių ligų išsivystymas dar siejamas su PTPN22 genu, kuris ekspresuojamas T ląstelèse ir koduoja limfoidinio tirozino fosfatazę (LYP). Irrodyta LYP sąveika su neigiamomis reguliavimo kinazèmis, tokiomis kaip Csk, kurios gali stabdyti signalo kaskadą. Specifinis polimorfizmas keičia argininą ị triptofaną 620 padètyje. Hipotezuojama, kad šis polimorfizmas mažina LYP gebejjimą sąveikauti su tikslinėmis molekulėmis ir T-ląstelių receptorių signalizavimą. Šis polimorfizmas susijęs su 1 tipo CD bei 
reumatoidiniu artritu [23]. Autoimuninių ligų manifestavimui svarbus su citotoksiniais T limfocitais susijęs antigenas-4 (CTLA-4), ekspresuojamas ant aktyvuotų CD4+ ir CD8+ T-ląstelių membranų. Jis suriša kostimuliacines molekules, slopinančias T ląstelių aktyvaciją. CTLA-4 genai gali atlikti svarbų vaidmeni sinergijoje su HLA, vystantis tiek 1 tipo $\mathrm{CD}$, tiek autoimuniniam tiroiditui, tiek JIA. Žinoma, kad FOX-P3 ekspresuojamas CD4+ CD25+ reguliuojančiose T ląstelèse, o mutacijos sukelia nesugebèjimą generuoti šias reguliuojančias ląsteles. Tai lemia kelių organų autoimuninius procesus [24].

Kitas kelių autoimuninių ligų (tokių kaip JIA ir 1 tipo CD) išsivystymas galètų būti siejamas su AIRE mutacijomis. Autoimuninis reguliatorius (AIRE) yra 21q22.3 chromosomoje, turi homologiją su transkripcijos veiksniais ir lokalizuotas branduolyje. Dažnos mutacijos daro įtaką AIRE gebejjimui lokalizuotis branduolyje ir sumažèjusiai transkripcijos aktyvacijai. Eksperimentai parodè, kad AIRE inicijuoja periferinių antigenų (antigenų, paprastai ekspresuojamų audiniuose, esančiuose už imuninès sistemos ribų) transkripciją šlaunies kamieninèse epitelio ląstelèse [20]. Šios mutacijos nustatomos tiek 1 tipo CD pacientams, tiek sergantiems JIA. 1 tipo CD yra susijęs su papildomų autoimuninių ligų (JIA) buvimu, susijusių su organui būdingų autoantikūnų gamyba. Šie autoantikūnai gali būti naudojami tiriant 1 tipo CD turinčius asmenis dèl autoimuniteto, susijusio su klinikine liga. Daliai tiriamujų̧, kuriems būdingi organams specifiški autoantikūnai, išsivysto klinikinė liga [25] (1 pav.).

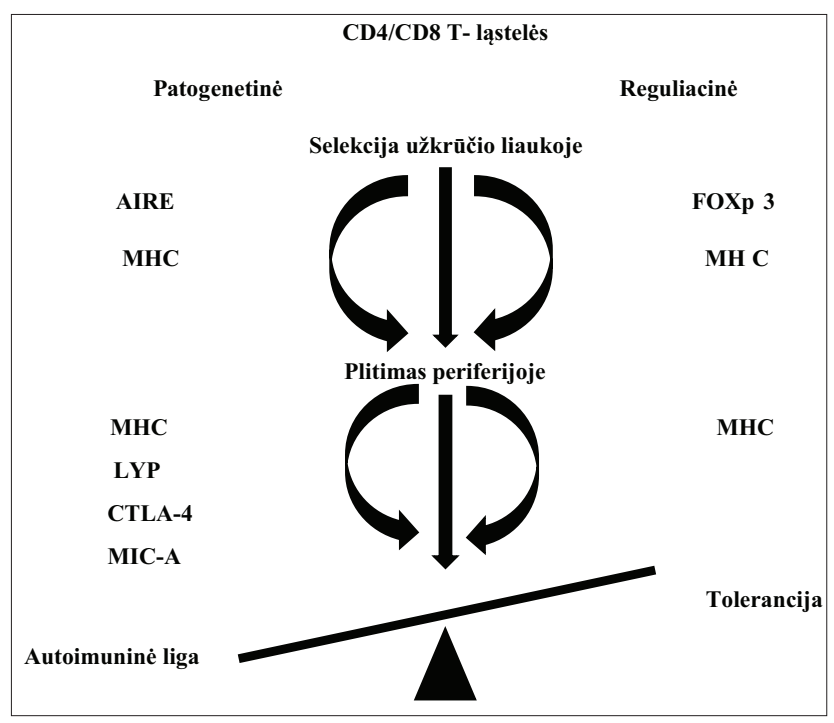

1 pav. Patogeninių ir reguliuojančių T ląstelių raida [20]:

$C D$ - diferenciacijos klasteris, AIRE - autoimuninio reguliatoriaus genas, FOXP3 - šakutès dėžutès baltymas 3; MHC - pagrindinis histo suderinamumo kompleksas, LYP - limfoidine tirozino fosfatazé; CTLA-4 - citotoksinis T-limfocitu antigenas 4, MIC-A - su MHC I susijęs genas A.
Citotoksinis T-limfocitų antigenas 4 (CTLA-4) yra Tlimfocitu paviršiaus molekulè ir atlieka imunologiškai svarbų vaidmenį, mažinant imuninio atsako reguliavimą. Sumažejęs imuninis atsakas gali atsirasti dèl konkuruojančio prisijungimo prie CD80/86, kuris neleidžia T-ląstelei stimuliuoti per CD28, arba slopina T-ląstelès signalizaciją, ribojant turimo T ląstelès receptoriaus (TCR) $\zeta$ kiekị. Dèl pagrindinio CTLA-4 vaidmens imuninèje funkcijoje, jo genetinè variacija buvo plačiai ištirta daugelyje autoimuninių sutrikimų, iskaitant JIA. CTLA-4 + 49A/G polimorfizmas 1 egzone susijęs su keliais autoimuniniais sutrikimais [26]. Kelių iš šių genų derinys baigiasi tolerancijos sau praradimu ir dèl to atsirandančia autoimunine ar autouždegimine patologija [27]. Palyginamoji 15 imuninių ligų analizè atskleidè, kad 1 tipo CD genetiškai panašesnis ị kitas autoantikūnų ligas, labiausiai ị juvenilinị idiopatinị artritą ir mažiausiai ị opinị kolitą [25]. Genetiniai tyrimai parodè ryšį tarp tam tikrų jautrumo geno lokusų mutacijų ir 1 tipo CD su JIA. Fenotipiškai skirtingoms autoimuninèms ligoms būdingi tie patys genetinio jautrumo veiksniai [3].

Ligą modifikuojančių antireumatinių vaistų poveikis 1 tipo CD. Neseniai atliktų suaugusiujų tyrimų duomenys parodè, kad LMARV, tokių kaip tumoro nekrozès faktoriaus alfa (TNF- $\alpha$ ) inhibitorių ir (ar) hidroksichlorokvino vartojimas gali sumažinti susirgimų dažnį ar pavèlinti 2 tipo CD pasireiškimą, reumatoidiniu artritu (RA) sergantiems pacientams [28,29]. Pastebèta, kad pacientams, sergantiems RA, sumažèjo atsparumas insulinui, vartojant TNF- $\alpha$ inhibitorius. Yra duomenų, kad padidejus insulino receptorių tirozinkinazės aktyvumui, pagerėjo skeleto raumenų gliukozès ịsisavinimas [28,30]. Šiuo metu pagrindinis dėmesys skiriamas uždegimo sustabdymui, naudojant priešuždegimines ir imuninę sistemą slopinančias gydymo strategijas, iskaitant metotreksato ir TNF- $\alpha$ inhibitorių terapiją [31]. Pirmo tipo cukrinis diabetas - tai genetinių ir aplinkos veiksnių nulemta autoimuninè liga, kai yra sukeliamas Langerhanso salelių uždegimas dèl T ir B limfocitų infiltracijos ir antikūnų (GAD-65, IAA, ZnT8) gamybos prieš kasos beta ląsteles. Buvo pastebèta, kad taikant terapiją monokloniniais antikūnais, tokiais kaip anti-CD3, anti-CD20 galima slopinti T-limfocitų auto-reaktyvumą, taip blokuojant 1 tipo CD autoimuninị ligos vystymosi kelią [32]. Vokietijos nacionalinès vaikų reumatologinės duomenų bazės (NPRD) duomenimis, sergančiujų 1 tipo CD kartu su JIA, insulino poreikis buvo mažesnis, nei sergančiujų tik diabetu (atitinkamai 0,55 TV/ $\mathrm{kg}$ per parą ir 1,03 TV/kg per parą). Paaiškèjo, kad pacientai, sergantys JIA su 1 tipo CD ir vartojantys mažai insulino, dažniau buvo gydomi biologiniais LMARV, o pacientai, kuriems buvo nustatytas JIA ir didesnis insulino poreikis, buvo rečiau gydomi biologiniais LMARV (atitinkamai 33,0\% ir 21,4\%) [3]. G. Hermann ir kt. nustate žymiai ankstesnius 1 
tipo CD pasireiškimus pacientams, sergantiems JIA, palyginti su pacientais, kuriems nebuvo JIA (mediana: atitinkamai 7,2 ir 8,3 metų, $\mathrm{p}=0,04$ ) [5]. Manoma, kad sumažèjęs 1 tipo CD pasireiškimas vyresnio amžiaus pacientams, sergantiems JIA, gali būti susijęs su JIA skiriama LMARV terapija [3].

\section{Išvados}

1. Daugèjant duomenų apie keleto autoimuninių ligų sąsajas, vis dažniau kalbama apie JIA ir 1 tipo CD vaikų amžiuje.

2. Kol kas nèra galutinai aiškūs JIA ir 1 tipo CD išsivystymo mechanizmai, tačiau galimi keletas šių ligų bendros patogenezès variantų:

2.1. HLA genų polimorfizmas gali lemti daugybinių autoimuninių ligų, ịskaitant juvenilinị idiopatinị artritą ir 1 tipo $\mathrm{CD}$, atsiradimą;

2.2. AIRE mutacijos gali būti siejamos su kelių autoimuninių ligų, tokių kaip JIA ir 1 tipo $\mathrm{CD}$, išsivystymu. Be to, sutrikusi pusiausvyra tarp patogeninių bei reguliacinių $\mathrm{T}$ limfocitų lemia tolerancijos sau praradimą ir taip paskatina autoimuninius ar autouždegiminius procesus.

3. Daugėja mokslinių studijų, tyrinejjančių LMARV poveiki 1 tipo CD vystymuisi. Pastebeta, kad šie vaistai turi apsaugini efektą, t.y. pacientams, sirgusiems JIA ir 1 tipo $\mathrm{CD}$, insulino reikèjo mažiau, jei jie vartojo LMARV. Be to, vartojant LMARV JIA metu, 1 tipo CD pasireiškè vèliau.

4. Reikalingi tolimesni lètinių autoimuninių ligų, tokių kaip 1 tipo CD ir JIA, tarpusavio sąsajų, bendrų patogenetinių mechanizmų ir gydymo taktikos tyrimai, kad pagerètų mažujų pacientų gyvenimo kokybẻ ir mažètų komplikacijų dažnis.

\section{Literatūra}

1. Prakken B, Albani S, Martini A. Juvenile idiopathic arthritis. Lancet 2011;377:2138-49.

https://doi.org/10.1016/S0140-6736(11)60244-4

2. Lee H, Jin Y, Liu J, et al. The risk of diabetes mellitus in patients with juvenile idiopathic arthritis. JRheum 2019:190644.

https://doi.org/10.3899/jrheum.190644

3. Schenck S, Rosenbauer J, Niewerth M, Klotsche J, Minden $\mathrm{K}$, Schwarz T, et al. Comorbidity of type 1 diabetes mellitus in patients with juvenile idiopathic arthritis. J Pediatr 2018;192:196-203

https://doi.org/10.1016/j.jpeds.2017.07.050

4. Pohjankoski H, Kautiainen H, Korppi M, Savolainen A. Simultaneous juvenile idiopathic arthritis and diabetes mellitus type 1-a finnish nationwide study. JRheum 2012;39:377-81.

https://doi.org/10.3899/jrheum.110654

5. Hermann G, Thon A, Monkemoller K, Lilienthal E, Klinkert C, Holder M, et al. Comorbidity of type 1 diabetes and juvenile idiopathic arthritis. J Pediatr 2015;166:930-5. https://doi.org/10.1016/j.jpeds.2014.12.026

6. Robazzi TC, Adan LF, Pimentel K, Guimarães I, Magalhães Filho J, Toralles MB, et al. Autoimmune endocrine disorders and coeliac disease in children and adolescents with juvenile idiopathic arthritis and rheumatic fever. Clin Exp Rheumatol 2013;31:310-7.

7. Pohajankoski H, Kautiainen H, Korppi M, Savolainen A. Simultaneous juvenile idiopathic arthritis and diabetes mellitus type 1 - a finnish nationwide study. JRheum 2012;39(2):377-381. https://doi.org/10.3899/jrheum.110654

8. Hollenbach JA, Thompson SD, Bugawan TL, Ryan M, Sudman M, Marion M, et al. Juvenile idiopathic arthritis and HLA class I and class II interactions and age-at-onset effects. Arthritis Rheum 2010;62:1781-1791. https://doi.org/10.1002/art.27424

9. Mayer-Davis EJ, Lawrence JM, Dabelea D, et al. Incidence trends of type 1 and type 2 diabetes among youths, 2002-2012. N Engl J Med 2017;376(15):1419-1429. https://doi.org/10.1056/NEJMoa1610187

10. IDF diabetes atlas. Brussels, Belgium: International Diabetes Federation, 2019. https://www.diabetesatlas.org/

11. Mayer-Davis EJ, Kahkoska AR, Jefferies C, et al. ISPAD clinical practice consensus guidelines 2018: definition, epidemiology, and classification of diabetes in children and adolescents. Pediatr Diabetes 2018;19 Suppl 27:7.

https://doi.org/10.1111/pedi.12773

12. Higienos institutas. https://stat.hi.lt/default.aspx?report_id $=168$

13. Schenck S Jr, Niewerth M, Klotsche J, Minden K, Schwarz T, Foeldvari I, et al. Comorbidity of type 1 diabetes mellitus in patients with juvenile idiopathic arthritis. J Pediatr 2017;192:196-203.

https://doi.org/10.1016/j.jpeds.2017.07.050

14. Gutierrez-Roelens I, Lauwerys BR. Genetic susceptibility to autoimmune disorders: clues from gene association and gene expression studies. Curr Mol Med 2008;8:551-61. https://doi.org/10.2174/156652408785747906

15. Krzewska A, Ben-Skowronek I. Effect of associated autoimmune diseases on type 1 diabetes mellitus incidence and metabolic control in children and adolescents. Biomed Res Int 2016;2016: 6219730 .

https://doi.org/10.1155/2016/6219730

16. Hersh AO, Prahalad S. Immunogenetics of juvenile idiopathic arthritis: a comprehensive review. J Autoimmun 2015;64:113-124. https://doi.org/10.1016/j.jaut.2015.08.002

17. Klareskog L, Rönnelid J, Holm G. Immunopathogenesis and immunotherapy in rheumatoid arthritis: an area in transition. J Intern Med 1995;238(3):191-206. https://doi.org/10.1111/j.1365-2796.1995.tb00923.x

18. Palucka AK, Blanck JP, Bennett L, Pascual V, Banchereau J . Cross-regulation of TNF and IFN-alpha in autoimmune diseases. Proc Natl Acad Sci USA 2005;102:3372-3377.

https://doi.org/10.1073/pnas.0408506102 
19. Hanukoglu A, Mizrachi A, Dalal I, Admoni O, Rakover Y, Bistritzer Z, Levine A, Somekh E, Lehmann D, Tuval M, Boaz M, Golander A. Extrapancreatic autoimmune manifestations in type 1 diabetes patients and their first-degree relatives: a multicenter study. Diabetes Care 2003;26(4):1235-1240.

https://doi.org/10.2337/diacare.26.4.1235

20. Barker JM. Type 1 diabetes-associated autoimmunity: natural history, genetic associations, and screening. JCEM 2006;91(4):1210-1217.

https://doi.org/10.1210/jc.2005-1679

21. Lambert AP, Gillespie KM, Thomson G, et al. Absolute risk of childhood-onset type 1 diabetes defined by human leukocyte antigen class II genotype: a population-based study in the United Kingdom. JCEM 2004;89(8):4037-4043. https://doi.org/10.1210/jc.2003-032084

22. Gambelunghe G, Ghaderi M, Cosentino A, et al. Association of MHC class I chain-related a (MIC-A) gene polymorphism with type I diabetes. Diabetologia 2000;43(4):507-514. https://doi.org/10.1007/s001250051336

23. Bottini N, Musumeci L, Alonso A, et al. A functional variant of lymphoid tyrosine phosphatase is associated with type I diabetes. Nat Genet 2004;36(4):337-338. https://doi.org/10.1038/ng1323

24. Ueda H, Howson JM, Esposito L, et al. Association of the Tcell regulatory gene CTLA4 with susceptibility to autoimmune disease. Nature 2003;423(6939):506-511. https://doi.org/10.1038/nature01621

25. Onengut-Gumuscu S, Chen WM, Burren O, et al. Fine mapping of type 1 diabetes susceptibility loci and evidence for colocalization of causal variants with lymphoid gene enhancers. Nat Genet 2015;47(4):381-386.

https://doi.org/10.1038/ng.3245

26. Gough SC, Walker LS, Sansom DM. CTLA4 gene polymorphism and autoimmunity. Immunol Rev 2005;204:102-115. https://doi.org/10.1111/j.0105-2896.2005.00249.x

27. Phelan JD, Thompson SD, Glass DN. Susceptibility to JRA/ JIA: complementing general autoimmune and arthritis traits. Genes Immun 2006:7:1-10. https://doi.org/10.1038/sj.gene.6364273

28. Antohe JL, Bili A, Sartorius JA, Kirchner HL, Morris SJ, Dancea S, et al. Diabetes mellitus risk in rheumatoid arthritis: reduced incidence with anti-tumor necrosis factor a therapy. Arthritis Care Res (Hoboken) 2012;64:215-21.

https://doi.org/10.1002/acr.20657

29. Solomon DH, Massarotti E, Garg R, Liu J, Canning C, Schneeweiss S. Association between disease-modifying antirheumatic drugs and diabetes risk in patients with rheumatoid arthritis and psoriasis. JAMA 2011;305:2525-2531.

https://doi.org/10.1001/jama.2011.878

30. Chen HH, Chen DY, Lin CC, Chen YM, Lai KL, Lin CH. Association between use of disease-modifying antirheumatic drugs and diabetes in patients with ankylosing spondylitis, rheu- matoid arthritis, or psoriasis/psoriatic arthritis: a nationwide, population-based cohort study of 84,989 patients. Ther Clin Risk Manag 2017;13:583-592.

https://doi.org/10.2147/TCRM.S130666

31. Fröhlich-Reiterer EE, Rosenbauer J, Bechtold-Dalla Pozza S, Hofer SE, Schober E, Holl RW, et al. Predictors of increasing BMI during the course of diabetes in children and adolescents with type 1 diabetes: data from the German/Austrian DPV multicentre survey. Arch Dis Child 2014;99(8):738-743.

https://doi.org/10.1136/archdischild-2013-304237

32. Raskin P, Mohan A. Emerging treatments for the prevention of type 1 diabetes. Expert Opin Emerg Drugs 2010;15:225-36. https://doi.org/10.1517/14728211003694631

\section{CORRELATION BETWEEN TYPE 1 DIABETES MELLITUS AND JUVENILE IDIOPATHIC ARTHRITIS IN CHILDREN \\ G. Gečaitė, A. Šnipaitienè, M. Malinauskas, L. Jankauskaitè}

Keywords: diabetes mellitus, children, juvenile idiopathic arthritis, autoimmune disease.

Summary

The aim of this study was to evaluate, systematize, and analyze data from the scientific literature on the association of pediatric type 1 diabetes mellitus (T1D) with juvenile idiopathic arthritis (JIA). This systematic review analyzes 11 full-text articles. A higher prevalence of T1D in JIA was observed compared to the non-JIA group and, conversely, a higher prevalence of JIA in the T1D population was found compared to the non-T1D group. Several observational studies have shown an increased incidence of diabetes in patients with JIA compared to the general population. Better knowledge of comorbidities in T1D associated with JIA in children and adolescents could help identify complications, help guide long-term disease management, and establish prognosis.

Conclusions. With increasing data on the links between several autoimmune diseases, there is growing interest in the connection between JIA and T1D in children. The mechanisms of JIA and T1D development are not yet fully understood, but several variants of the common pathogenesis of these diseases are possible: a) HLA gene polymorphism can lead to multiple autoimmune diseases, including juvenile idiopathic arthritis and T1D; b) AIRE mutations may be associated with the development of several autoimmune diseases such as JIA and T1D. In addition, the disturbed balance between pathogenic and regulatory $\mathrm{T}$ lymphocytes results in a loss of self-tolerance and thus initiates autoimmune or auto-inflammatory processes. In the recent years more scientific studies are investigating the effects of DMARDs on the development of T1D. These drugs have been observed to have a protective effect: patients with both JIA and T1D required less insulin if they were taking DMARDs. Moreover, T1D occurred later in JIA if treated with DMARDs. Further research is needed into the interrelationships, common pathogenetic mechanisms and treatment tactics of chronic autoimmune diseases such as T1D and JIA to improve the quality of life of young patients and reduce the incidence of complications.

Correspondence to: a.snipaitiene@gmail.com Gauta 2020-06-02 